\title{
Consumers' complaint behaviour. Taxonomy, typology and determinants: Towards a unified ontology
}

Received (in revised form): 16th August, 2003

\section{Dominique Crié}

is Professor of marketing at the University of Sciences and Technologies of Lille, in the Business Administration Department (IAE). He manages the postgraduate degree course: statistical specialisation for marketing databases. He is also a marketing consultant and statistician, member of the Association Française de Marketing and of the Société Française de Statistiques. His research focuses on the customer relationship, particularly in relation to satisfaction, loyalty and retention.

\begin{abstract}
Complaint behaviour is a set of consumer dissatisfaction responses. It is an explicit expression of dissatisfaction, but dissatisfaction is only one determinant of this behaviour. Complaint behaviour can be analysed as various types of response but also as a process. This paper proposes an integrated framework of the various theories of complaint behaviour leading toward a unified ontology and to interpreting it from a new perspective.
\end{abstract}

\section{INTRODUCTION}

This paper reviews a concept still relatively rarely considered by companies: consumer complaint behaviour. Within the framework of the relationship paradigm, complaint behaviour is a powerful signal which companies should take into account. On the one hand, it gives an organisation a last chance to retain the customer, if the organisation reacts appropriately, on the other hand it is a legitimate and ethical act toward the consumer.

Generally, but not exclusively, complaint behaviour is one of the responses to perceived dissatisfaction in the post-purchase phase. In the first IAE de Lille, 104, Avenue du Peuple Belge, 59043 Lille Cédex, France.

Tel: +33 (0)3201234 64 Fax: +33 (0)3 201234 48; E-mail: DomiCrie@aol.com section of the paper, a taxonomy of response styles used by dissatisfied consumers is proposed. Then consumer complaint behaviour (CCB) is defined and situated with regard to these various types of response. Finally, after clustering 'complainers' and 'non-complainers', this paper tries to track down the main dimensions of the CCB taxonomy through a structuralisation of its determinants within a diachronic approach — the objective being to propose a clarified conceptual and theoretical framework to integrate the large variety of works on the subject. The conclusion highlights a synthesis of this conceptual structure with regard to a unified ontology.

\section{A TAXONOMY OF THE TYPES OF RESPONSE TO DISSATISFACTION}

A dissatisfied consumer may adopt several types of response, classification of which may be delicate. The taxonomy of responses first requires a distinction between the notions of response and of action to be established. Indeed, the term 'action' implies a very specific behaviour, 
Table 1: A taxonomy of the types of response to dissatisfaction

\begin{tabular}{|c|c|c|}
\hline \multirow[b]{2}{*}{ Response type } & \multicolumn{2}{|l|}{ Towards enitity } \\
\hline & $\begin{array}{l}\text { Public } \\
\text { (Sellers, manufacturers, official organisations, } \\
\text { associations, justice) }\end{array}$ & $\begin{array}{l}\text { Private } \\
\text { (Family, friends, } \\
\text { relations) }\end{array}$ \\
\hline Behavioural & $\begin{array}{l}\text { Complaint } \\
\text { Legal action } \\
\text { Return of the item } \\
\text { Request for repair }\end{array}$ & $\begin{array}{l}\text { Word of mouth } \\
\text { Boycott/leaving }\end{array}$ \\
\hline Non-behavioural & $\begin{array}{l}\text { No action, with or without modification } \\
\text { of the attitude } \\
\text { Forget or forgive }\end{array}$ & \\
\hline
\end{tabular}

while the term 'response' contains several modalities which are not exclusively behavioural, notably change of attitude or inactivity. This distinction establishes a first dimension.

The second is represented by the entities towards which responses are directed: the public one includes sellers, manufacturers and consumer associations or legal action; the private one includes family, friends or relatives.

Finally, responses show different intensities according to the two previous dimensions. Responses may vary from inactivity to legal action - either simply to express dissatisfaction or to obtain repair or compensation (Table 1 ).

The heterogeneity of these various response types may be partially explained by the cause and intensity of dissatisfaction and by the nature and importance of the product or service of concern. On the other hand, consumers may mix or connect several response types for the same dissatisfaction. This aspect is relatively neglected by the literature, although Hirschman ${ }^{1}$ notes that complaint and exit are not two symmetric elements: when a customer leaves the company, he/she loses 'the opportunity' to use their voice, while if he/she uses the complaint first, he/she is always free to leave later if the complaint does not succeed. So exit can be a substitute for and complement to a complaint.
The more expensive and complex the product, the more consumers are inclined to initiate public action, however the greater likelihood is that they will stay inactive or choose private action. $^{2-4}$

The authors of the first stream of literature are numerous, but Hirschman's work remains standard in the conceptualisation of responses to dissatisfaction through the model 'Exit, Voice and Loyalty'. Exit is an active and destructive response to dissatisfaction, exhibited by a break of the relationship with the object (brand, product, retailer, supplier...). The verbal response (Voice) is a constructive response with an expectation of change in an organisation's practices, policies and responses; it is characterised by complaints towards friends, consumer associations and relevant organisations. The third type of response (Loyalty) has two aspects, constructive and passive, the individual hoping that things will evolve in a positive way. For Brown and Swartz, ${ }^{5}$ it is especially a feeling of impotence that is the cause of this behavioural loyalty. 'The neglect of the incident and the inherent inactivity' can, however, be considered as evidence for loyalty.

Research designed to explain the various types of response to dissatisfaction is limited. Scales have been created for this purpose by Day et al. ${ }^{6}$ but they are without methodological and 
psychometric validation. Only Bearden and $\mathrm{Teel}^{7}$ have investigated the various types of response using a Guttman scale. The data are collected from five items of increasing intensity: (1) family and friends warning, (2) return of the item and/or complaint, (3) contact with the manufacturer, (4) contact with consumer associations or official organisations and (5) legal action, notably when the customer does not obtain satisfaction with the seller. ${ }^{8}$ Empirically validated, this scale does not, however, take into account the non-behavioural responses highlighted by previous research, and a single item relates to private action. ${ }^{9}$ Of a rather formative nature, every item contributes in its own way to the development of the intensity of the responses. Day ${ }^{10}$ confirms the relevance of the use of such a scale.

The main aim of this taxonomy is to clarify the various responses a dissatisfied consumer could use, in order to track down more precisely those which the company can observe directly.

\section{DEFINING CONSUMER COMPLAINT BEHAVIOUR}

Among the various types of response to dissatisfaction, some of them more direcly concern CCB. The first conceptual base of this phenomenon concerning post-purchase was stated at the end of the 1970s. ${ }^{11}$ Jacoby and Jaccard $^{12}$ define it as 'an action begun by the individual who entails a

communication of something negative to a product (service), either towards the company or towards a third entity'. For Day et al., ${ }^{13}$ it is the consequence 'of a given act of consumption, following which the consumer is confronted with an experience generating a high dissatisfaction, of sufficient impact so that it is, neither likened psychologically, nor quickly forgotten'. Fornell and
Wernerfelt ${ }^{14}$ consider that the complaint is 'an attempt of the customer to change an unsatisfactory situation'. Finally, Singh $^{15}$ suggests that this behaviour, activated at an emotional or sentimental level by a perceived dissatisfaction, is part of the more general framework of responses to dissatisfaction which consists of two dimensions (see also Day and Landon $\left.{ }^{16}\right)$. The first dimension, grounded completely or in part in actions initiated by the consumer (conveying expression of his/her dissatisfaction not only to the seller, but also to third parties, friends or relations ${ }^{17,18}$ ), is behavioural but does not necessarily entail action towards the company; it is essentially within this dimension that CCB should be considered. The second dimension refers to absence of action by the consumer, for example when he/she forgets a generative episode of dissatisfaction. ${ }^{19,20}$ In this way, CCB must, rather, be conceived as a process, ie its final manifestation does not directly depend on its initiating factors but on evaluation of the situation by the consumer and of its evolution over time.

So, CCB really constitutes a subset of all possible responses to perceived dissatisfaction around a purchase episode, during consumption or during possession of the good (or service). In fact, the notion of 'complaint behaviour' includes a more general terminology which also involves the notions of protest, communication (word of mouth) or recommendation to third parties ${ }^{21}$ and even the notion of boycott. This notion is conceptually inserted in a set of explicit demonstrations, generally towards the seller, of a consumer's dissatisfaction. It seems then that it is necessary to include in the definition of CCB a set of responses, heterogeneous in their targets - the study of this behaviour not being separable from understanding of all the responses to dissatisfaction. 


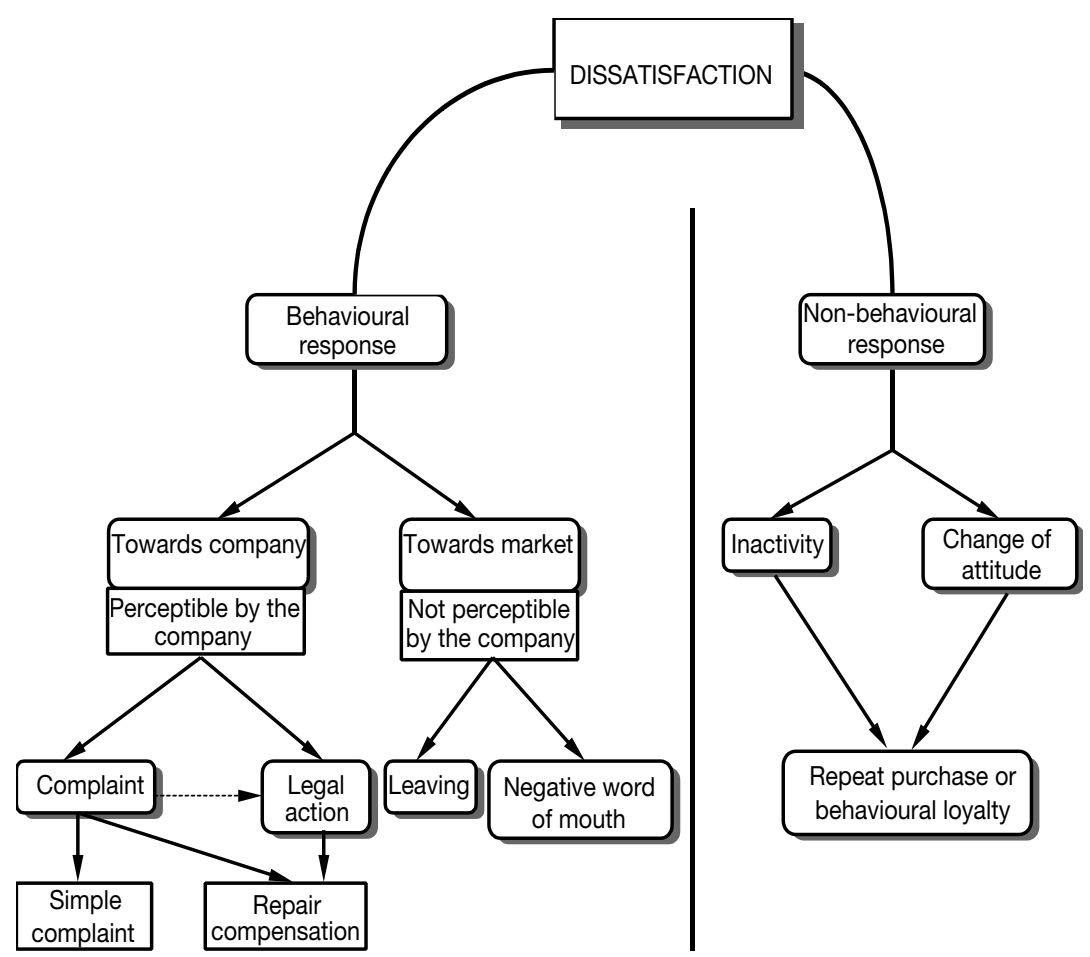

Figure 1: Responses to dissatisfaction and complaint behaviour

In the rest of this paper, therefore, the term 'complaint behaviour' is used in the conceptual meaning of a public behavioral response to dissatisfaction.

So, for a company, only part of these responses will be perceptible, including complaint in the sense described previously (Figure 1). On the other hand, it is the retailer who will be most affected by CCB. The manufacturer is seldom sought out, so such crucial information reaches him only rarely, and often not at all. ${ }^{22,23}$

\section{A TYPOLOGY OF DISSATISFIED CONSUMERS}

Several authors have tried to individualise groups of consumers with regard to the type of response adopted in the wider framework of dissatisfaction. Most researchers offer a 'normative typology' within which the 'complainers' can be placed but without really distinguishing particular groups. These are opposed to the 'non-complainers', ${ }^{24-27}$ in this way these works are more concerned with responses to dissatisfaction than $\mathrm{CCB}$ in its strict sense. They are poor in terms of possible categories and are not grounded in a rigorous analysis of response styles. Certain typologies nevertheless allow a few specific behaviours in the expression of $\mathrm{CCB}$ to be extracted, for example the 'irritated actives', ${ }^{28,29}$ the 'activists', ${ }^{30}$ the 'complainers', the 'irates', ${ }^{31}$ the 'voicers', ${ }^{32}$ the 'slightly offended' or the 'champions'. ${ }^{33}$

For Hirschman ${ }^{34}$ the complaint must be considered as feedback on the quality delivered by the company, the 'complainers' are called 'alert customers' (because they allow the company to improve the product or service) as 
Table 2: Main types of complainers

\begin{tabular}{|c|c|c|c|c|}
\hline Behaviour & Public action & Authors & Private action & Authors \\
\hline $\begin{array}{l}\text { Complaint } \\
\text { (prostestation) }\end{array}$ & $\begin{array}{l}\text { Voicers } \\
\text { Champions } \\
\text { Complainers }\end{array}$ & $\begin{array}{l}\text { Dart and Freeman } \\
\text { Weiser }^{36} \\
\text { Etzel }^{37} \\
\text { Shuptrine } \\
\text { Bearden }^{39} \\
\text { Day }^{40} \\
\text { Gronhaug and Zaltman }^{41} \\
\text { Singh } \\
\text { Keng }^{43}\end{array}$ & $\begin{array}{l}\text { Slightly offended } \\
\text { Irates }\end{array}$ & $\begin{array}{l}\text { Weiser }^{52} \\
\text { Dart }^{53} \\
\text { Singh }^{54}\end{array}$ \\
\hline $\begin{array}{l}\text { Request for } \\
\text { repair }\end{array}$ & $\begin{array}{l}\text { Active upsets } \\
\text { Irritated }\end{array}$ & $\begin{array}{l}\text { Masson }^{44} \\
\text { Warland }^{45} \\
\text { Singh }^{46}\end{array}$ & & \\
\hline $\begin{array}{l}\text { Measures of } \\
\text { retaliation }\end{array}$ & $\begin{array}{l}\text { Detractors } \\
\text { Activists }\end{array}$ & $\begin{array}{l}\text { Weiser }^{47} \\
\text { Pfaff }^{48} \\
\text { Warland }^{49} \\
\text { Singh } \\
\text { Dart }^{51}\end{array}$ & Lost in action & Weiser $^{55}$ \\
\hline
\end{tabular}

opposed to 'inert customers'. The complaint is then a factor of enhancement for company performance.

Taken as a whole the typology of dissatisfied consumers overlaps with that of the responses to dissatisfaction and develops its structure at the same time as the intensity of the CCB modalities chosen by consumers, going from simple complaint to retaliatory measures in a register of public or private actions (Table 2).

Generally speaking, the various typologies outlined do not allow retailers or manufacturers to appreciate the complexity and variety of CCB in order to respond in an effective way, but it is likely that certain behaviours will be more specific in a given situation. For example, within the framework of a dissatisfaction bound to durable goods (high price and high commitment), one would tend to observe among 'complainers' a stronger proportion of 'irritated actives' or 'irates'. In a weakly competitive market they will tend to be 'activists'. If the usual quality level of products is weak, 'detractors' and 'irates' will be observed. Finally, within the framework of a well-established relationship a majority of 'champions' or 'slightly offended people' would be expected.

\section{TOWARDS A DIACHRONIC APPROACH TO CCB}

The literature does not propose a systematisation in the organisation of antecedents and determinants of CCB. This deficiency is essentially due to the fact that CCB is regarded as an immediate act and not as a process. In fact, this concept lacks a clearly identified theoretical framework which allows the organisation of a heterogeneous set of factors that initiate and modulate it and which can take into account resemblances and differences that also comply with the more global notion of dissatisfaction responses. Indeed, an ambiguity in the study of CCB results from the fact that it should not include, by semantic definition, the non-behavioural aspect of responses to dissatisfaction or customers leaving. The 
diachronic nature of the phenomenon of complaint could probably explain similarities and differences which exist between these two concepts.

The number of implied variables strengthens the idea that $\mathrm{CCB}$ is not an instantaneous phenomenon, it is the outcome of a process of preliminary evaluations under the influence of initiating and modulating factors. This approach also raises the question of the effect of time on a consumer's initial impulse to complain. CCB occurs after increasing reflection by the consumer. ${ }^{56-57}$ and Stephens and Gwinner, ${ }^{58}$ offer the first longitudinal approach to $\mathrm{CCB}$ on the basis of in-depth interviews. For them, CCB results from a double cognitive evaluation. ${ }^{59}$ The first is defined as a process by which the individual estimates how much influence a particular situation, in a given environment, has on his/her well being. The second may be analysed as a problem resolution strategy. The CCB depends then on the situation and on the psychological resources of the individuals. Within this framework, it is then relevant to think that generally the intention to complain or protest must occur at the same time as dissatisfaction and under the influence of initiating factors. This primary intention is then the object of various distorting or modulating factors meaning that the final outcome is often different from that intended, it can be highly altered or just not come about at all. This idea then leads to the consideration of a number of non-behavioural responses to dissatisfaction or responses not perceptible by the company (cf. Figure 1) as being in some way failed CCBs. It is thus relevant to analyse how this intention arises and changes over time. After a phase of initiation represented by the initial level of dissatisfaction, then a phase of reflection necessary for the integration of its cause and for the evaluation of the possible responses, there follows a phase of decision and of action which will in fact reflect only the residual dissatisfaction at the conclusion of the process. This remaining dissatisfaction can nevertheless be reinforced to reach a higher level than that of the initial dissatisfaction, for example if the consumer is strengthened in his/her decision, either by the problem worsening, by the salesperson's attitude or by the encouragement of third parties. In that case, measures taken by the consumer can be more significant than those initially intended. Nevertheless the process does not stop with the voicing of the complaint, it also includes evaluation of the company's response and concludes with the final behaviour which ensues from it (repurchase or exit).

It is then advisable to restore, in a diachronic framework, various streams of literature whose main object is to explain the result of this process. Indeed, when researchers take time into account in $\mathrm{CCB}$, it is essentially the available time to protest that is considered ${ }^{60}$ and not the period separating the episode of dissatisfaction from the response to it. But, the procedural knowledges are connected in time. They echo information relative to processes, that is to say sequences of actions, or sequences of reasoning in the sense that they order, or at least structure, the progress of several operations, possibly several procedures. This cognitive approach to complaint behaviour places it totally within the framework of a decision process.

\section{TOWARDS AN INTEGRATION OF THE VARIOUS ANTECEDENTS AND DETERMINANTS OF CCB}

In a simplistic way and besides its diachronic aspect, it is possible to distinguish within the conceptual part of the literature related to the determinants 


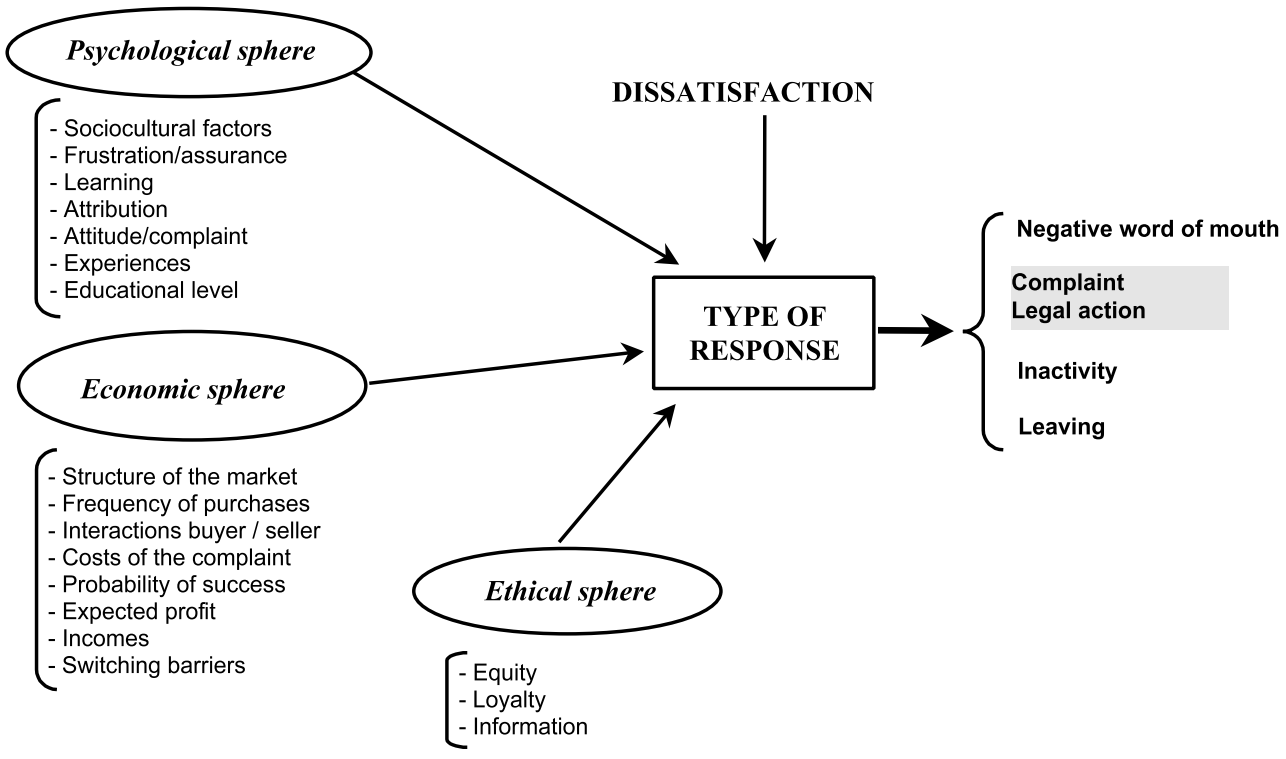

Figure 2: Antecedents and determinants of CCB

of CCB, three spheres of factors which interact with different weights to lead, eventually, to CCB or to other modalities of response to dissatisfaction such as defined above.

The psychological sphere is made up of individual variables reflecting the propensity to CCB. The economic sphere groups together elements of cost and exchange structures. Finally, the ethical sphere incorporates transactional equity, concentrating on the perception of the value of the link with the company and on the accuracy and helpfulness of the information given, for example, regarding ways to resolve the disputes, etc (Figure 2).

On the other hand, the diachronic approach to CCB requires its various antecedents and determinants to be anchored on two points: first on the initiating factors and secondly on the factors modulating the mode of complaint. This point of view allows not only integration of the various explanatory theories and the synthesis described above but also for a short path to complaint to be distinguished from a long one. This distinction, notably, can take into account the role of time and of both types of factors on CCB. In a short path the influence of the modulating factors is less, the complaint occurring mostly at the sale point, almost simultaneously with delivery of the product or service. It is an immediate emotional reaction rather than an extended process. In a long, extended path, however, there are more modulating factors which seem to shape the type of response. (The variables of the ethical sphere work as initiators, those of the economic sphere have a modulator role and those of the psychological sphere can be classified as either type.)

On the whole, four entities are directly involved in CCB: the product or service, the customer, the supplier and the episode of dissatisfaction. These various actors allow, within the framework of a diachronic approach, the multiple antecedents and determinants of CCB (Table 3) to be re-ordered. 
Table 3: Various determinants of CCB according to the stage and the actor

\begin{tabular}{|c|c|c|}
\hline $\begin{array}{l}\text { Stage of CB } \\
\text { Actor }\end{array}$ & Initiation of $\mathrm{CB}$ & Modulation of CB \\
\hline Product/service & Dissatisfaction level & $\begin{array}{l}\text { Structure of the market } \\
\text { Alternatives } \\
\text { Purchase rate } \\
\text { Price, complexity of the } \\
\text { product/service }\end{array}$ \\
\hline Customer & $\begin{array}{l}\text { Perceived frustration } \\
\text { Perceived inequity } \\
\text { Assurance (self control) } \\
\text { Will to act } \\
\text { Primary evaluation of the dissatisfaction }\end{array}$ & $\begin{array}{l}\text { Attitude, Experience/CB } \\
\text { Learning, Information/CB } \\
\text { Loyalty } \\
\text { Education, Age, Sex } \\
\text { Ethnicity } \\
\text { Way of life } \\
\text { Secondary evaluation of response } \\
\text { possibilities }\end{array}$ \\
\hline Supplier & $\begin{array}{l}\text { Quality defect } \\
\text { Incident/product or service }\end{array}$ & $\begin{array}{l}\text { Absence of management of post } \\
\text { purchase } \\
\text { Ease of access to the company } \\
\text { Switching barriers } \\
\text { Switching costs } \\
\text { Customer/seller interactions } \\
\text { Size of the company, business sector }\end{array}$ \\
\hline $\begin{array}{l}\text { Episode } \\
\text { Situation, } \\
\text { circumstances }\end{array}$ & $\begin{array}{l}\text { Dissatisfaction attribution } \\
\text { Time-spatial simultaneity of the } \\
\text { dissatisfaction and response possibilities }\end{array}$ & $\begin{array}{l}\text { Expected profit } \\
\text { Transaction costs of CB } \\
\text { Probability of success } \\
\text { Importance of consumer organisations }\end{array}$ \\
\hline
\end{tabular}

\section{Initiating factors of CCB}

Several factors may lead to CCB. Introducing and determining, partly, a consumer's choice of a given type of response to dissatisfaction, they allow on the one hand a better understanding of consumers' motivation for $\mathrm{CCB}$ and, on the other hand, a forecast of what response will be the most likely to be adopted. Ordinarily consumers need to be dissatisfied in order to complain but other variables are necessary to switch from dissatisfaction to complaint. Such variables may lie in attribution of the cause of dissatisfaction or in psychosociological characteristics of the individual consumer (see Table 3).

\section{Dissatisfaction}

Dissatisfaction is a necessary antecedent of CCB, but is often not sufficient ${ }^{61,62}$ (see also Jacoby and Jaccard, ${ }^{63}$
Westbrook ${ }^{64}$ and Ping ${ }^{65}$ on the notion of complaint without dissatisfaction $\left.{ }^{66}\right)$. It is the activating factor of the process. ${ }^{67}$ Besides, Oliver ${ }^{68}$ underlines the existing relationship between the intensity of the dissatisfaction and this behaviour. ${ }^{69}$ Grandbois et al. ${ }^{70}$ Richins, ${ }^{71}$ Maute and Forrester $^{72}$ prove that the gravity of the problem is correlated in a positive way with the various responses to dissatisfaction including CCB. The more the dissatisfaction increases, the more the verbal complaint strengthens and the more the probability of leaving the company grows. For Singh and Pandya, ${ }^{73}$ the relationship 'intensity-type of response' is not linear and admits threshold effects. When the level of dissatisfaction exceeds a given threshold consumers tend to use either negative word of mouth or leaving or appeal to a third party. On the other hand, the relationship between attitude to the 
complaint and CCB itself can be modulated by the intensity of the dissatisfaction. ${ }^{74-76}$

\section{Attribution of the cause of the dissatisfaction}

To lead to CCB, the consumer has to identify clearly the party responsible for his or her dissatisfaction during a given consumption episode (Table 3). In numerous cases it is the consumer himself/herself, for example when he/she judges he/she did not make the right choice. So, even if for Valle ${ }^{77}$ the attribution of responsibility for dissatisfaction operates as an intermediary between the confusion and the response which follow, it is advisable to classify it as an initiating factor of CCB.

According to Weiner et al. ${ }^{78}$ a success or failure can be attributed either to elements under the control of the individual (internal cause[s]), or to environment or situational factors (external cause[s]). On the other hand, the performance can be attributed to invariant factors (stable) or evolving with time (unstable). The type of attribution achieved by the consumer determines $a$ priori the response that may be chosen. If an external attribution is necessary for a private type action, a legal action or a request for repair, in the case of an internal attribution it is especially inactivity which dominates. ${ }^{79}$ Usually, consumers who perceive the cause of their dissatisfaction as being stable (the same problem may recur) or controllable (the individual thinks that the retailer could have prevented the trouble) are more inclined to leave the product or the company and to engage in negative word of mouth than those who think that the problem has little chance of recurring and that the supplier could not prevent it (see also Folkes ${ }^{80}$ ).

\section{Psychosociological factors}

Some individual characteristics are to be considered as initiators of CCB, although they can also play a modulating role according to the situation (Table 3 ). Fornell and Westbrook, ${ }^{81}$ according to Mischel, ${ }^{82}$ associate CCB with the feeling of frustration felt by a dissatisfied consumer. Frustration arises not only when the objective assigned to a given behaviour is blocked or interrupted before its fulfilment, but also when the result achieved has a lower level than that sought, or when its realisation requires more resources than the consumer can, wants or expects to spend to reach the desired objective. This feeling is also present when the means to reach the satisfaction, both at the resources level and at the wanted object level (product or brand), are reduced or suppressed. Along the same lines, frustration can arise in situations of purchase intention (unavailability of the product or of the brand) or in post-purchase situations (dissatisfaction of use or of ownership). The more substantial the frustration, the greater the risk of aggressiveness and CCB.

For Stephens and Gwinner ${ }^{83}$ the stress of dissatisfaction adds to the daily stress and CCB is connected to a double evaluation of the situation during a cognitive process. Three constituents form the primary evaluation of the stress: (1) the level of modification of the individual objectives; (2) the incongruity between these objectives and the incident; (3) the level of the person's ego infringement (humiliation, self-esteem, ethical values). A second evaluation of possible response strategies is then initiated according to: (1) the responsibility attribution for the confusion; (2) the possibility of solving the problem (capacities of the individual, probability of success); (3) the feeling that things will go better afterwards. If 
the resulting stress of the primary evaluation can be reduced by a solving strategy (secondarily estimated), the probability of $\mathrm{CCB}$ is great. If, on the other hand, this strategy risks increasing the initial stress, the main probability turns out to be a non-behavioural response or a response towards the market (see Figure 1).

Other individual characteristics may also influence the start of a complaint process, ${ }^{84}$ eg loyalty to the brand, product or supplier; the level of quality assessment, the educational level and tastes; the ability to detect quality differences (a function of experience) and the acquired level of information; perception of the 'cost/profit' ratio of the possible actions.

For Lapidus and Pinkerton, ${ }^{85}$ the consumer-retailer relationship is one of social exchange and, therefore, equity theory may be applied in order to explain the initiation of CCB. The consumer compares his/her inputs/outputs ratio with those that he/she perceives to be received by the seller. Naturally this comparison can be biased according to the trend (positive or negative) of the revealed inequity. The complaint appears then as an attempt to reduce the perceived inequity (see also Blodgett et al. ${ }^{86}$ ). Secondly, the costs inherent in the complaint and its perceived outcome can be considered as inputs and outputs of this theory.

Finally, learning theory can also be mentioned: the inclination to $\mathrm{CCB}$ is essentially a function of past experiences $^{87-90}$ and of their outcome. ${ }^{91}$

\section{Modulator factors of CCB}

Dissatisfaction can be organised around two congruent factors: the former is situational, the latter temporal. It can indeed occur where the product is purchased or the service is delivered and thus be immediate, but it can also take place at a distance from the act of purchase. In the same way, the response to dissatisfaction can be either immediate or deferred. So the CCB can consist of rather a short path in the case of a dissatisfaction on the spot and of an immediate response, or a long circuit in the case of delayed dissatisfaction with regard to the purchase act or of a postponed response. It is then, especially in this last situation, that numerous variables can intervene to modify the consumer's actual response, by moderating or aggravating it: ultimately the intensity of the CCB will thus depend on an evaluation of the situation during a temporal process. The market structure, sociocultural characteristics or evaluation of the various costs associated with $\mathrm{CCB}$ will act as modulators of the process outcome.

\section{The market structure}

The market structure can be regarded as an element influencing the response type choice adopted by a dissatisfied consumer (see Table 3). For Hirschman, ${ }^{92}$ consumers are ready to voice their complaints in two circumstances: (1) the way they balance the certainty of leaving and the uncertainty of an improvement in the product or service quality and (2) the estimation they make of their capacity to influence the organisation by voicing their concerns. These two factors are far from being independent. Fornell and Didow ${ }^{93}$ situate CCB in the larger field of rational choice - with the slight difference that choice in economic theory is in the pre-purchase period, while CCB is generally a post-purchase phenomenon. The objects of choice are also different: products and services in the first case, type of response in the second. In this theoretical framework, they show that verbal action can be 
expressed as a preference function and as the possibility of purchasing elsewhere.

Indeed, in a restricted competitive environment, verbal action will be the only possible action for a dissatisfied consumer. ${ }^{94,95}$ In contrast, when competitors are numerous, the customer's leaving becomes the most likely reaction and his/her action is then situated at the market level (see Figure 1). Therefore, the market structure appears as a powerful determinant of CCB. On the other hand, and within this framework, sensitivity of the various customer segments, either to price or quality, shapes the dominant response type to dissatisfaction. Those sensitive to price may leave the company, those sensitive to quality are more inclined to complain. ${ }^{96}$

It also seems that buyer-seller interaction frequency (ie purchase rate) plays a part in the preference for verbal action. ${ }^{97}$ The more frequent these interactions the fewer the public actions. ${ }^{98}$ On the other hand, Barksdale et al. ${ }^{99}$ report that the lower the level of purchase at the same supplier, the greater the tendency to CCB. New purchases lead to more complaints and the usual suppliers receive more complaints than the new ones.

For Weiser, ${ }^{100}$ the degree of ease of access to the company and the willingness of the customer to complain are determining elements in the choice of a response type. In a more specific way, Andreasen ${ }^{101}$ emphasises, within the framework of nearly monopolistic markets or markets perceived as such, that the response type is a function of the: perceived heterogeneity of the offer quality; level of knowledge; level of perceived switching costs; probability of success of a verbal action both for the individual and the community; supposed complaint level of other consumers; and the degree of loyalty to the product, brand or supplier.
The attractiveness of the alternatives or the availability of substitutable goods shows a strong relationship with the response type adopted by the consumer. ${ }^{102}$ In the same way, the more important the company the more the number of complaints. ${ }^{103,104}$

Day et al. ${ }^{105}$ classify in three categories the factors which can influence the propensity to CCB: (1) the circumstances defining the interests at work and evaluation of the costs and likely profits of a search for compensation; (2) the characteristics of the individuals or the situation surrounding the costs and the purely psychological profits of alternative actions, as well as the general tendency of the mediation interventions; (3) market conditions and the legal climate. For Day et al., this latter category determines the probability of a favourable outcome to the action taken. Generally speaking this type of action will also depend on the nature of the product or service, the usable channels of complaint and the third parties which could intervene.

On the other hand, for Andreasen and Best ${ }^{106}$ the inclination of consumers to perceive problems depends on the nature of the exchange. For services this propensity is greatest, because they are, by nature, more difficult to assess (see Shuptrine and Wenglorz, ${ }^{107}$ Bearden and Masson ${ }^{108}$ ). But there is also a unit of time and place during service delivery which favours $C C B$. Referring to the attribution theory, Zeithaml and Bitner ${ }^{109}$ consider that because the customer is an actor in service delivery, the customer appropriates more willingly a part of responsibility in his/her dissatisfaction and tends to protest less often.

\section{Sociocultural factors}

Some sociocultural factors have to be acknowledged as modulators of the complaint process (see Table 3). For Day 
et al., ${ }^{110}$ (1) the standards of life and the effectiveness of the marketing system, (2) the degree of regulation and control of economic activities and marketing practices and (3) the availability of information to help consumers make their choice or to know where to complain, represent three groups of characteristics to be taken into account for a cross-cultural approach to the phenomenon.

Richins, ${ }^{111}$ within the framework of an international comparison, shows that in the USA the factors most correlated to CCB are price, the difficulty the consumer faces in resolving the confusion by himself and the attribution of the cause of dissatisfaction. In the Netherlands Richins found the correlating factors were price, responsibility for the damage and its felt intensity. The most determinative variables remain the attribution of responsibility and the perceived consequences of a complaint, two variables less correlated to $\mathrm{CCB}$ in the American sample.

Cornwell, Bligh and Babakus ${ }^{112}$ clearly highlight that ethnic origin plays an important role in CCB especially through values and the way of life. Webster ${ }^{113}$ also finds an influence of ethnic factors when the effect of social variables is controlled. Furthermore, women generally have a greater inclination to complain and people living in rural areas are more prone to negative word of mouth. ${ }^{114}$

For Farhangmehr and Silva, ${ }^{115}$ educational level is a determining variable; the higher it is the more consumers tend to complain in a dissatisfaction situation (see Gronhaug, ${ }^{116}$ Morganosky and Buckley ${ }^{117}$ ). In their study, the reasons for silence on the part of the consumer are: the effort and waste of time involved (44.7 per cent) which can be compared with the expected gain; the feeling of not being understood or that the problem will not be resolved (30.3 per cent); and not knowing where and how to complain
(21.1 per cent) which is related to the consumer's information level. Obviously these proportions can vary with the opinion that consumers have about the possibility of resolution of their problem according to the sector or company concerned. ${ }^{118}$

Gronhaug and Zaltman ${ }^{119}$ show that economic indicators such as income have only a weak explanatory power and that it is the same for demographic factors. ${ }^{120-123}$ For Singh ${ }^{124}$ the 'complainers' tend to have superior incomes, a higher educational level, are still working and are younger (also Bearden et al. ${ }^{125}$ ). Laforge ${ }^{126}$ indeed shows that elderly people complain less, this in agreement with the sociological theory of learned helplessness which makes the individual passive because he/she perceives the situation as uncontrollable.

\section{The costs of the complaint}

In reference to the works of Landon, ${ }^{127}$ the profit of a complaint is a function of the result minus the cost of complaint. This result is itself estimated with regard to the importance and the nature of the damage sustained. The consumer's preference for verbal action is then related to the expected value of the complaint outcome (connected with the importance of the dissatisfaction) minus the associated costs. ${ }^{128}$ The latter depend notably on the image of the company, especially in the resolution of disputes, on the consumer's experience of CCB and on the nature of the dispute. An arbitration is thus achieved between cost and profit of every possible action so as to gain maximum utility. ${ }^{129}$

Gronhaug and Gilly ${ }^{130}$ use transaction costs theory ${ }^{131}$ in order to explain the various consumer responses to dissatisfaction. Three dimensions of this theory (specificity, uncertainty and exchange frequency) can be invoked to 
explain CCB. Does approaching the distributor or manufacturer entail specific costs? Generally, CCB requires time and effort thus generating a mixture of different types of costs, eg opportunity cost of the elapsed time, deliberation costs, transportation costs - these can be called CCB transaction costs. These costs are specific to the envisaged response type whether it is actual or not. They cannot be paid off afterwards, at best they could be used as a learning stage in order to reduce them during a later complaint. Uncertainty arises from any transaction (ie complaint) and the consumer looks for information to reduce this uncertainty to a bearable level. Finally, the complaint frequency has a direct influence on its organisation, possibly becoming a 'routine', thus reducing the associated costs. This theory thus explains more frequent $\mathrm{CCB}$ when consumers have superior educational level: they know their rights so the level of uncertainty associated with the complaint is reduced and there is, therefore, a global decrease of the perceived costs of a complaint.

Nevertheless, as a general rule, the majority of dissatisfied customers do not complain. Kolodinsky ${ }^{132}$ insists moreover on the assessment, by the consumer, of the temporal cost of the choice of an appropriate response. Furthermore, as the search for a new product or supplier also generates numerous costs, it is often the case that the dissatisfied consumer refrains from any action. ${ }^{133,134}$

\section{MANAGERIAL IMPLICATIONS FOR HANDLING COMPLAINTS}

Businesses are, too often, completely hopeless at dealing with complaints, although complaint management has become an important issue for many companies. Some elements of the various theories mentioned above allow managers to understand better the complaint process in order to cope with it better. First of all, and within the framework of relationship marketing, complaint management is a major strategic issue. On the one hand complaint management has a retention function in the sense that where a customer satisfied with the treatment of his/her complaint gets a second-order feeling of satisfaction his/her confidence with the company is strengthened. Thus companies that respond to consumer dissatisfaction and complaints with appropriate recovery strategies and satisfactory complaint resolution can turn dissatisfied consumers into satisfied ones, positively influencing repurchase rates (eg Bearden and Oliver ${ }^{135}$ ). To decrease the effect of dissatisfaction and the incidence of further negative actions, companies need to show, at the least, that they are responsive to legitimate complaints. But, if problems are resolved poorly, they are only the beginning of a multitude of 'hidden' actions which do not come to the attention of the business. So, proper handling of customer complaints improves repeat patronage intentions and reduces negative word of mouth. ${ }^{136}$ Finally, in dealing with complaints, truly marketing-oriented companies must examine not only the costs of the remedy, but also the cost of not settling the complaint.

The usual rationale is that complaints represent valuable feedback to companies that allows them to take corrective action vis-à-vis the defective product or service as regards either the critical incidents ${ }^{137}$ or adjustment of the offer to match customer expectations.

Both actions are of strategic nature: the first is concerned with customer relationship management and retention, the second with an equally long-term strategy, ie continuous improvement of the product or service in order to fit customer expectations. 
From an operational point of view, the complaints handling process begins before the customer addresses his/her complaint to the seller or manufacturer. All must be done in order that the various costs associated with this behaviour are reduced, so that complaints are encouraged, facilitated and even solicited in order for companies to take corrective action. Kotler ${ }^{138}$ suggests that the best thing a retailer can do is to make it easy for a customer to complain. For example, Saint Maclou, a French

nationally-advertised carpet manufacturer and retailer, indicates on each bill the name of the person to contact if a problem arises and, if the trouble remains unresolved, the name of a more empowered executive is given. Access to the company thus has to be multichannel. The customer must be assured that he/she will be listened to and that his/her problem will probably be successfully resolved. Lastly, and according to justice theory, the consumer must be conscious that the failure will be corrected fairly, that is to say with impartiality, transparency, effectiveness and fairness. As the majority of dissatisfied consumers leave the company without complaining, managers have to overcome customers' natural disinclination to complain.

Thus this process is concerned with service recovery, that is to say, the rectification of mistakes or compensation of customers. Service recovery is defined as the response a provider makes to a service failure; ${ }^{139}$ service failure usually requires dissatisfaction on the part of the customer. It begins with thanks for the approach by the customer: salespeople or staff need to learn to use 'complaint welcoming' procedures. Then the complaint must be listened to. Psychologically speaking it is important for the customer to cope with his/her frustration through a kind of debriefing by oral or written expression of the trouble. For instance, complaint letters to Railtrack in the UK rose to an all time high in 2001, without the writers realistically expecting any immediate benefit other than the ability to articulate their frustration. Complaint, especially voice, gives the customer an opportunity to 'tell their side of the story' which serves as a kind of reward for the customer. ${ }^{140}$ Furthermore, Levy and Weitz $^{141}$ argue that a salesperson's willingness to listen can be an important source of consumer dissatisfaction and complaint intentions. A salesperson's willingness to listen has been described as the degree of attentiveness a person shows. ${ }^{142}$ According to Palmroth, ${ }^{143}$ a salesperson must ask questions until s/he understands the full nature of the complaint without appearing to place blame on the customer. These salespeople should be seen as trustworthy, friendly, expert, honest, helpful and concerned. The third step is concerned with the acknowledgment of the failure, if justified. (If not, it is necessary to explain why and, according to the attribution theory, to gently point out the misuse of the service or product. It should also be noted that some consumers may complain not out of dissatisfaction but in an effort to gain fraudulently from retailers or manufacturers.) This is, however, related to the salesperson's familiarity with the product and awareness of any possible problems with the merchandise in question. Apologies are the next step and empowered contact employees must be able to offer immediate redress where possible or advice on the way to proceed, always in order to reduce customers' costs and frustration. Indeed, of customers who register a complaint, about 60 to 75 per cent will do business with the provider again if their complaint has been resolved, and this 
figure goes up to 95 per cent if the customer feels that the complaint was resolved quickly. Furthermore, providing compensation is a common response to customer complaints. In addition to the tangible benefits received, customers typically see the compensation as a symbolic expression of regret by the provider. ${ }^{144}$ In a word, courteous and fast treatment by front office personnel can enhance favourable post-complaint responses ${ }^{145}$ and staff must persuade the customer that all will be done to ensure that the trouble does not recur. Other authors provide some rules of thumb. For example, Davidow ${ }^{146}$ presents a model framework that divides the organisational responses to complaint into six separate dimensions: timeliness, facilitation, redress, apology, credibility and attentiveness. Nevertheless, according to Mitchell, ${ }^{147}$ a study shows that 51 per cent of his sample who had complained about a service and 23 per cent about products were less than completely satisfied with the responses they received.

The importance of regulatory authorities in determining how complaints should be managed in a marketing sense, and their active involvement in researching this area and setting standards should also be noted. Generally speaking the legal analysis assumes that it is important that companies are involved in fixing problems with consumers. But more often, sector-based organisations are proactive and promulgate codes of conduct or of deontology in order to provide a conventional frame for a wide range of business activities, including complaints. For instance, Consumer Complaint Form (CCform; coordinated by the Federation of European Direct Marketing) is a European Commission Information Society Technology funded project to reach a consensus between business, consumers, academics and regulators on new, more efficient and transparent processes for complaints management. The CCform project aims to develop an online, multilingual complaint form and a best practice business process. With CCform, consumers will be able to make complaints in their own language, and then the form will be translated into the companies' preferred tongue. Note that cultural norms appear to change the way people react to dissatisfaction and so the response type. Consumers will be able to track the progress of their complaint, and, if necessary, escalate their grievance to a dispute resolution service or regulator. CCform can be used by any company doing business by e-commerce, distance selling or local retail operations. ${ }^{148}$ Complainants may have recourse to a third party and an escalation in the process can result. In this sense, the complaint handling can also be seen as a dispute prevention mechanism.

On the other hand, and from a customer relationship management point of view, CCB is an important early warning. Furthermore, Powers and Bendall-Lyon ${ }^{149}$ have shown that the number of complaints increased as a result of the introduction of a complaint management programme in an hospital context. Complaint management programmes enable organisations to receive complaint information in order to identify and accommodate dissatisfied customers and identify common failure points in order to improve service quality. Each complaint either by phone, face to face, letter or e-mail, should be recorded in the database. The manager should be able to link each product, customer and complaint together. For example, a customer with an increasing complaint rate may be in a leaving phase and should be carefully monitored. Indeed, and although customer 
relationship management aims to establish and maintain ongoing customer relationships by focusing on the specific customer's needs in order to deliver high levels of customer satisfaction and company loyalty, one major aspect of customer relationship management is the effective handling of customer complaints.

\section{CONCLUSION AND FUTURE RESEARCH}

This paper allows CCB to be placed and defined within the larger framework of responses to dissatisfaction and then suggests an integrating framework of diachronic nature. Until now research into $\mathrm{CCB}$ has taken a deductive approach, researchers trying to deduce its causes from contextual or individual elements without being really interested in the process taking place in a temporal space of variable duration.

The various works of literature studied offer different explanations for CCB but few of them consider the sequence and interaction of initiating or modulating factors in a process. CCB is indeed essentially described in its immediate nature, that is to say as an instantaneous event. Nevertheless, the nature and intensity of response to dissatisfaction certainly depend on the type of experience and on the responsible product/service but they also involve two other actors (the supplier and the customer) in a diachronic framework. The variability of individual reactions, notably revealed by the lack of a clear typology of 'complainers and noncomplainers', results from a different weighting of constitutive elements of the process over time.

The joining together and organisation of these elements, from which three large areas can be isolated (the utilitarian sphere of the economists, the ethical sphere of equity and the psychological sphere, notably represented by attribution), supply a synthetic approach by describing CCB in two stages: initiation and modulation. The initiation phase is related to the dissatisfaction level which determines the opening of the process. It is then followed by a search for attribution of the problem and by the perception of the inequitable character of the transaction engendering frustration or stress which the individual will try to minimise. It is during the evaluation of the problem resolution strategies that modulators, such as experience and attitude towards the complaint, personality of the individual and his/her sensitivity to quality, will or will not allow the process to evolve towards the actual complaint. Other factors of this type can be isolated, such as loyalty level and information level, the degree of nearness (commitment) in the relationship with the supplier, the market structure (particularly the possibility of choice alternatives) and finally, the hoped/expected utility of the complaint with regard to the perceived costs as well as the accessibility of the company for $\mathrm{CCB}$. If $\mathrm{CCB}$ is taken to be a process it becomes easy to link together all the response types following an episode of dissatisfaction and this knowledge is helpful for complaints handling, eg in encouraging the customer to complain or in avoiding his leaving. The TARP study ${ }^{150}$ indeed indicates that 90 per cent of dissatisfied consumers initiate no action and leave the product, brand or company.

So, the managerial implications arise not only from contextual factors but also from the diachronic aspect of the phenomenon. Although initiators are only weakly accessible to action by the manager, except by avoiding dissatisfaction and by strengthening the perceived equity of transactions, some 
modulators can be amended so as to lead the dissatisfied customer to complain more frequently. Thus the company can contribute to the modification of consumers' attitudes towards CCB by: rendering more favourable the perception of previous experiences; restoring a feeling of equity after a complaint; decreasing the costs, particularly the psychological ones; and finally, establishing interpersonal relationships that reduce the attraction of alternatives. It is necessary to reward customers who complain by including them in this step and by getting them used to this cultural change.

It is necessary to insist on the urgency of a dissatisfaction communication to the company and to shorten the response delay (free phone number, specific coupon, website, CCform...) in order to minimise the negative constituents of the modulators. From a passive role of complaint reception, the company has to evolve towards a proactive stage in the genesis and the actual expression of CCB. It is then necessary to gather information about dissatisfaction as quickly as possible in order to divert a process which would otherwise probably lead to the customer leaving. So, complaints must be regarded more as a marketing tool than as a cost (better service to the customer and customer retention); they constitute a fundamental element of relationship marketing.

This synthesis should encourage the number of research studies into the diachronic side of $\mathrm{CCB}$, in the sense that any dissatisfaction (of external attribution) requires that the consumer get in touch with the company. So, the relationship between dissatisfaction, complaint intention and actual response deserve to be clarified in connection with time. It is also advisable to analyse more exactly consumers' expectations of complaints. It is indeed by satisfying these expectations that marketers can hope to increase the number of 'complainers'.

\section{References}

1 Hirschman, A. O. (1970) 'Exit, voice and loyalty: Responses to decline in firms, organizations and states', Harvard University Press, Cambridge, MA.

2 Day, R. and Landon, E. Jr. (1977) 'Toward a theory of consumer complaining behavior' in Woodside, Sheth and Bennett (eds) 'Consumer and industrial buying behavior', North Holland Publishing Co., Amsterdam, pp. 425-437.

3 Richins, M. L. (1987) 'A multivariate analysis of responses to dissatisfaction', Journal of the Academy of Marketing Science, Vol. 15, No. 4, pp. 24-31.

4 Levesque, T. J. and McDougall, G. H. G. (1996) 'Customer dissatisfaction: The relationship between types of problems and customer response', Canadian Journal of Administrative Sciences, Vol. 13, No. 3, pp. 264-276.

5 Brown, S. and Swartz, T. (1984) 'Consumer medical complaint behavior: Determinants of and alternatives to malpractices litigation', Journal of Public Policy and Marketing, Vol. 3, pp. 85-98.

6 Day, R. L., Grabicke, K., Schaetzle, T. and Staubach, F. (1981) 'The hidden agenda of consumer complaining', Journal of Retailing, Vol. 57, No. 3, pp. 86-106.

7 Bearden, W. O. and Teel, J. E. (1983) 'Selected determinants of consumer satisfaction and complaint reports', Journal of Marketing Research, Vol. 20, No. 1, pp. 21-28.

8 Barnes, J. and Kelloway, K. R. (1980) 'Consumerists: Complaining behavior and attitude toward social and consumer issues', Advances in Consumer Research, Vol. 7, pp. 329-334.

9 Singh, J. (1988) 'Consumer complaint intentions and behavior: Definitional and taxonomical issues', Journal of Marketing, Vol. 52, No. 2, pp. 93-107.

10 Day, R. L. (1984) 'Modeling choices among alternative responses to dissatisfaction', Advances in Consumer Research, Vol. 11, pp. 496-499.

11 Day and Landon (1977) op. cit.

12 Jacoby, J. and Jaccard, J. J. (1981) 'The sources, meaning and validity of consumer complaining behavior; A psychological review', Journal of Retailing, Vol. 57, No. 3, pp. 4-24.

13 Day et al. (1981) op. cit.

14 Fornell, C. and Wernerfelt, B. (1987) 'Defensive marketing strategy by customer complaint management: A theoretical analysis', Journal of Marketing Research, Vol. 24, No. 4, pp. 337-346. 15 Singh (1988) op. cit.

16 Day and Landon Jr. (1977) op. cit.

17 Day (1984) op. cit.

18 Richins, M. L. (1983) 'Negative word of mouth by dissatisfied consumers: A pilot study', Journal of Marketing, Vol. 47, No. 1, pp. 68-78.

19 Hirschman (1970) op. Cit.

20 Day and Landon Jr. (1977) op. cit. 
21 Mooradian, T. A. and Olver, J. M. (1997) 'I can't get no satisfaction: The impact of personality and emotion on postpurchase processes', Psychology and Marketing, Vol. 14, No. 4, pp. 379-393.

22 Kolodinsky, J. (1995) 'Usefulness of economics in explaining consumer complaints', The Journal of Consumer Affairs, Vol. 29, No. 1, pp. 29-54.

23 Lovelock, C. H. (1996) 'Services marketing', 3rd ed., Prentice Hall, New Jersey, pp. 473-480.

24 Day, R. (1980) 'Research perspectives on consumer complaint behavior', Lamb and Dunne (eds) 'Theoretical developments in marketing', AMA, Chicago IL, pp. 211-215.

25 Shuptrine, K. and Wenglorz, G. (1980) 'Comprehensive identification of consumer's marketplace problems and what they do about them', Advances in Consumer Research, Vol. 8, pp. 687-692.

26 Gronhaug, K. and Zaltman, G. (1981) 'Complainers and non-complainers revisited: Another look at the data', Advances in Consumer Research, Vol. 8, pp. 83-87.

27 Bearden and Teel (1983) op. cit.

28 Masson, J. B. and Himes, S. H. (1973) 'An exploratory behavioral and socio-economic profile of consumer action about a dissatisfaction with selected household appliances', Journal of Consumer Affairs, Vol. 7, No. 1, pp. 121-127.

29 Warland, R. H., Hermann, R. O. and Willis, J. (1975) 'Dissatisfied consumers: Who gets upset and who takes action', Journal of Consumer Affairs, Vol. 9, No. 2, pp. 148-163.

30 Pfaff, M. and Blivice, S. (1977) 'Socioeconomic correlates of consumer and citizen dissatisfaction and activism', in Day R. 'Consumer satisfaction, dissatisfaction and complaining behavior', Indiana University Press, Bloomington, pp. 115-123.

31 Singh, J. (1990) 'A typology of consumer dissatisfaction response styles', Journal of Retailing, Vol. 66, No. 1, pp. 57-98.

32 Dart, J. and Freeman, K. (1994) 'Dissatisfaction response styles among clients of professional accounting firms', Journal of Business Research, Vol. 29, No. 1, pp. 75-82.

33 Weiser, C. (1995), 'Customer retention: The importance of the "Listening Organisation", Journal of Database Marketing, Vol. 2, No. 4, pp. 344-358.

34 Hirschman (1970) op. cit.

35 Dart and Freeman (1994) op. cit.

36 Weiser (1995) op. cit.

37 Etzel, M. and Siverman, B. (1981) 'A managerial perspective on directions for retail customer satisfaction research', Journal of Retailing, Vol. 57, No. 3, pp. 124-136.

38 Shuptrine and Wenglorz, (1980) op. cit.

39 Bearden, W., Crockett, M. and Teel, J. (1980) 'A past model of consumer complaint behavior', in Bagozzi, R. P. (ed.) 'Marketing in the 80's: Changes and challenges', AMA Proceedings, Chicago, IL, pp. 101-104.

40 Day (1980) op. cit.
41 Gronhaug and Zaltman (1981) op. cit.

42 Singh (1988) and (1990) op. cit.

43 Keng, K. A., Richemond, D. and Han, S. (1995)

'Determinants of consumer complaint behaviour:

A study of Singapore consumers', Journal of

International Consumer Marketing, Vol. 8, No. 2, pp. 59-67.

44 Masson and Himes (1973) op. cit.

45 Warland (1975) op. cit.

46 Singh (1988) and (1990) op. cit.

47 Weiser (1995) op. cit.

48 Pfaff and Blivice (1977) op. cit.

49 Warland, R. H., Hermann, R. O. and Moore, D.

E. (1984) 'Consumer and community

involvement: An exploration of their theoretical and empirical linkages', Journal of Consumer Affairs, Vol. 18, No. 1, pp. 64-79..

50 Singh (1988) and (1990) op. cit.

51 Dart and Freeman (1994) op. cit.

52 Weiser (1995) op. cit.

53 Dart and Freeman (1994) op. cit.

54 Singh (1988) and (1990) op. cit.

55 Weiser (1995) op. cit.

56 Kolodinsky (1995) op. cit.

57 Conlon, D. E. and Murray, N. M. (1996) 'Customer perceptions of corporate responses to product complaints: The role of explanations', Academy of Management Journal, Vol. 39, No. 4, pp. 1040-1056.

58 Stephens, N. and Gwinner, K. P. (1998) 'Why don't some people complain? A cognitive-emotive process model of consumer complaint behavior', Journal of The Academy of Marketing Science, Vol. 26, No. 3, 172-189.

59 Lazarus, R. S. (1966) 'Psychological stress and the coping process', McGraw Hill, New York.

60 Kolodinsky (1995) op. cit.

61 Day (1984) op. cit.

62 Oliver, R. L. (1987) 'An investigation of the interrelationship between consumer (dis)satisfaction and complaint reports', Advances in Consumer Research, Vol. 14, pp. 218-222.

63 Jacoby and Jaccard (1981) op. cit.

64 Westbrook, R. A. (1987) 'Product/consumption based affective responses and postpurchase processes', Journal of Marketing Research, Vol. 24, No. 3, pp. 258-270.

65 Ping, R. A. (1993) 'The effects of satisfaction and structural constraints on retailer exiting, voice, loyalty, opportunism and neglect', Journal of Retailing, Vol. 69, No. 3, pp. 320-352.

66 These authors mention the possibility of complaint by satisfied consumers, either to try to obtain more from the company, or for fear of a future breakdown or because of doubt in the performance of the product or because of propensity to complain.

67 Singh, J. (1989) 'Determinants of consumer's decision making to seek third party redress: An empirical study of dissatisfied patients', The Journal of Consumer Affairs, Vol. 23, No. 2, pp. 329-363. 
68 Oliver, R. L. (1980) 'A cognitive model of the antecedents and consequences of satisfaction decisions', Journal of Marketing Research, Vol. 17, No. 4, pp. 460-469.

69 Day et al. (1981) op. cit.

70 Grandbois, D., Summers, J. O. and Frazier, G. L. (1977) 'Correlates of consumer expectation and complaining behavior', in Day, R. L. (ed.), 'Consumer satisfaction, dissatisfaction and complaining behavior', Indiana University Press, Bloomington, In.

71 Richins (1987) op. cit.

72 Maute, M. F. and Forrester, W. R. (1993) 'The structure and determinants of consumer complaint intentions and behavior', Journal of Economic Psychology, Vol. 14, No. 2, pp. 219-247.

73 Singh, J. and Pandya, S. (1991) 'Exploring the effects of consumers' dissatisfaction level on complaint behaviours', European Journal of Marketing, Vol. 25, No. 9, pp. 7-22.

74 Richins, M. (1982) 'An investigation of consumer's attitude toward complaining', Advances in Consumer Research, Vol. 9, pp. 502-606.

75 Richins, M. L. (1985) 'Seeking redress for consumer dissatisfaction: The role of attitude and situational factors', Journal of Consumer Policy, Vol. 8, No. 1, pp. 29-37.

76 Singh (1989) op. cit.

77 Valle, V. A. and Krishman, S. (1978)

'Dissatisfaction attributions and consumer complaint behavior', Advances in Consumer Research, Vol. 6, pp. 445-449.

78 Weiner, B., Frieze, I., Kukla, A., Reed, L. and Rosenbaum, R. M. (1972) 'Percieving the causes of success and failure', in Jones, E. E, et al. (eds) 'Attribution perceiving the causes of behavior', General Learning Press, Morristown, NJ, pp. 95-120.

79 Stephens and Gwinner (1998) op. cit.

80 Folkes, V. S. (1984) 'Consumer reactions to product failure: An attributional approach', Journal of Consumer Research, Vol. 10, No. 1, pp. 393-409.

81 Fornel, C. and Westbrook, R. A. (1979) 'An exploratory study of assertiveness, aggressiveness, and consumer complaining behavior', Advances in Consumer Research, Vol. 6 pp. 105-110.

82 Mischel, W. (1971) 'Introduction to personality', Holt, Rinehart and Winston Inc., NY, quoted by Fornell and Westbrook (1979).

83 Stephens and Gwinner (1998) op. cit.

84 Maute and Forrester (1993) op. cit.

85 Lapidus, R. S. and Pinkerton, L. (1995), 'Customer complaint situations: An equity theory perspective', Psychology and Marketing, Vol. 12, No. 2, pp. 105-118.

86 Blodgett, J. G., Grandbois, D. H. and Walters, R. G. (1993) 'The effect of perceived justice on complainant's negative word of mouth behavior and repatronage intentions', Journal of Retailing, Vol, 69, No. 4, pp. 399-426.

87 Jacoby and Jaccard (1981) op. cit.
88 Day (1984) op. cit.

89 Singh (1990) op. cit.

90 Hansen, S. W., Powers, T. and Swan, J. E. (1997) 'Modelling industrial buyer complaints: Implications for satisfying and saving customers', Journal of Marketing Theory and Practice, Vol, 5, No. 4, pp. 12-22.

91 Kolodinsky (1995) op. cit.

92 Hirschman (1970) op. cit.

93 Fornell and Didow (1980) op. cit.

94 Hirschman (1970) op. cit.

95 Kolodinsky (1995) op. cit.

96 Hirschman (1970) op. cit.

97 Andreasen, A. R. and Best, A. (1977)

'Consumers complain. Does business respond?', Harvard Business Review, Vol. 55, No. 4, pp. 93-101.

98 Fornell and Didow (1980) op. cit.

99 Barksdale, H. C., Powell, T. E. and Hargrove, E. (1984) 'Complaint voicing by industrial buyers', Industrial Marketing Management, Vol. 13, No. 2, pp. 93-100.

100 Weiser (1995) op. cit.

101 Andreasen, A. R. (1985) 'Consumer responses to dissatisfaction in loose monopolies', Journal of Consumer Research, Vol. 12, No. 2, pp. 135-141.

102 Maute and Forrester (1993) op. cit.

103 Oster, S. (1980) 'The determination of consumer complaints', Review of Economics and Statistics, Vol. 62, No. 4, pp. 603-609.

104 Kolodinsky (1995) op. cit.

105 Day et al. (1981) op. cit.

106 Andreasen and Best (1977) op. cit.

107 Shuptrine and Wenglorz (1980) op. cit.

108 Bearden, W. and Masson, J. (1984) 'An investigation of influences on consumer complaint reports', Advances in Consumer Research, Vol. 11, pp. 490-495.

109 Zeithaml, V. A. and Bitner, M. J. (1996) 'Services marketing', McGraw Hill, New York.

110 Day et al. (1981) op. cit.

111 Richins (1987) op. cit.

112 Cornwell, B. T., Bligh, A. D. and Babakus, E. (1991) 'Complaint behavior of MexicanAmerican consumers to a third-party agency', The Journal of Consumer Affairs, Vol. 25, Summer, pp. 1-18.

113 Webster, C. (1991) 'Attitudes toward marketing practices: The effects of ethnic identification', Journal of Applied Business Research, Vol. 7, No. 2, pp. 107-117.

114 Kolodinsky, J. (1993) 'Complaints, redress and subsequent purchases of medical services by dissatisfied consumers', Journal of Consumer Policy, Vol. 16, No. 2, pp. 193-214.

115 Farhangmehr, M. and Silva, M. (1995) 'Strategic importance of consumer's complaints: An empirical study', Marketing Today and for the 21th Century Proceedings of the 24th EMAC Conference; pp. 1595-1604.

116 Gronhaug, K. (1977) 'Exploring consumer complaining behaviour: A model and some 
empirical results', Advances in Consumer Research, Vol. 4, pp. 159-165.

117 Morganosky, M. A. and Buckley, H. M. (1987) 'Complaint behavior: Analysis by demographics, lifestyle and consumer values', Advances in Consumer Research, Vol. 14, pp. 223-226.

118 Anderson, E. W. and Sullivan, M. W. (1993) 'The antecedents and consequences of customer satisfaction for firms', Marketing Science, Vol. 12, No. 2, pp. 125-143

119 Gronhaug and Zaltman (1981) op. cit.

120 Warland, Hermann and Willis (1975) op. cit.

121 Jacoby and Jaccard (1981) op. cit.

122 Bearden, W. O. and Oliver, R. (1985) 'The role of public and private complaining in satisfaction in problem resolution', Journal of Consumer Affairs, Vol. 19, No. 2, pp. 222-240.

123 Singh (1990) op. cit.

124 Ibid.

125 Bearden, W., Crockett, M. and Teel, J. (1980) 'A past model of consumer complaint behavior', Bagozzi, R. P. (ed.) 'Marketing in the 80's: Changes and challenges', Proceedings AMA, Chicago IL, pp. 101-104.

126 Laforge, M. C. (1989) 'Learned helplessness as an explanation of elderly consumer complaint behavior', Journal of Business Ethics, Vol. 8, No. 5, pp. 359-366.

127 Landon, E. L. (1977) 'A model of consumer complaint behavior', Indiana University Press, Bloomington, pp. 31-35.

128 Fornell and Didow (1980) op. cit.

129 Hirschman (1970) op. cit.

130 Gronhaug, K. and Gilly, M. C. (1991) 'A transaction cost approach to consumer dissatisfaction and complaint actions', Journal of Economic Psychology, Vol. 12, No. 1, pp. 165-183.

131 Williamson, O. E. (1979) 'Transaction cost economics: The governance of contractual relations', Journal of Law and Economics, Vol. 22, No. 2, pp. 3-61.

132 Kolodinsky (1995) op. cit.

133 Technical Assistance Research Program Institute
(TARP) (1986) 'Consumer complaint handling in America: An update study, Parts I and II', TARP and US Office of Consumer Affairs, Washington DC', April.

134 Fornell and Wernerfelt (1987) op. cit.

135 Bearden and Oliver (1985) op. cit.

136 Blodgett, Grandbois and Walters (1993) op. cit.

137 Carlzon, J. (1988) 'Moments of truth', Harper \& Row, NY.

138 Kotler, P. (1997) 'Marketing management: Analysis, planning, implementation, and control', Prentice-Hall, Inc, Upper Saddle River, NJ.

139 Kelley, S. W. and Davis, M. A. (1994) 'Antecedents to customer expectations for service recovery', Academy of Marketing Science Journal, Vol. 22, No. 1, pp. 52-62.

140 Alexander, E. C. (2002) 'Consumer reactions to unethical service recovery', Journal of Business Ethics, Vol. 36, No. 3, pp. 223-237.

141 Levy, M. and Weitz, B. A. (1998) 'Retailing management, Irwin McGraw Hill, Boston, MA.

142 Palmroth, B. (1988) 'Welcome complaints', American Salesman, 3-5 July.

143 Ibid.

144 Conlon and Murray (1996) op. cit.

145 Blodgett, J. G., Hill, D. J. and Tax, S. S. (1997) 'The effects of distributive, procedural, and interactional justice on postcomplaint behaviour', Journal of Retailing, Vol. 73, No. 2, pp. 185-210.

146 Davidow, M. (2003) 'Organizational responses to customer complaints: What works and what doesn't', Journal of Service Research, Vol. 5, No. 3.

147 Mitchell, V. W. (1993) 'Handling consumer complaint information: Why and how?', Management Decision, Vol. 31, No. 3, pp. 21-28.

148 CCForm website at http://www.ccform.org

149 Powers, T. L. and Bendall-Lyon, D. (2002) 'Using complaint behaviour to improve quality through the structure and process of service delivery', Journal of Consumer Satisfaction, Dissatisfaction and Complaining Behavior, Vol. 15, pp. 13-21.

150 Technical Assistance Research Program Institute (TARP) (1986) op. cit. 